\title{
Interdisciplinary assessment of complex regional water systems and their future evolution: how socioeconomic drivers can matter more than climate
}

\author{
Emmanuel Reynard, ${ }^{1 *}$ Mariano Bonriposi, ${ }^{1}$ Olivier Graefe, ${ }^{2}$ \\ Christine Homewood, ${ }^{2}$ Matthias Huss, ${ }^{2}$ Martina Kauzlaric, ${ }^{3}$ \\ Hanspeter Liniger, ${ }^{4}$ Emmanuel Rey, ${ }^{3}$ Stephan Rist, ${ }^{4}$ Bruno Schädler, ${ }^{3}$ \\ Flurina Schneider ${ }^{4}$ and Rolf Weingartner ${ }^{3}$
}

\begin{abstract}
Modeling of future water systems at the regional scale is a difficult task due to the complexity of current structures (multiple competing water uses, multiple actors, formal and informal rules) both temporally and spatially. Representing this complexity in the modeling process is a challenge that can be addressed by an interdisciplinary and holistic approach. The assessment of the water system of the Crans-Montana-Sierre area (Switzerland) and its evolution until 2050 were tackled by combining glaciological, hydrogeological, and hydrological measurements and modeling with the evaluation of water use through documentary, statistical and interview-based analyses. Four visions of future regional development were co-produced with a group of stakeholders and were then used as a basis for estimating future water demand. The comparison of the available water resource and the water demand at monthly time scale allowed us to conclude that for the four scenarios socioeconomic factors will impact on the future water systems more than climatic factors. An analysis of the sustainability of the current and future water systems based on four visions of regional development allowed us to identify those scenarios that will be more sustainable and that should be adopted by the decision-makers. The results were then presented to the stakeholders through five key messages. The challenges of communicating the results in such a way with stakeholders are discussed at the end of the article. @ 2014 Wiley Periodicals, Inc.
\end{abstract}

\footnotetext{
*Correspondence to: emmanuel.reynard@unil.ch

${ }^{1}$ Institute of Geography and Sustainability, University of Lausanne, Lausanne, Switzerland

${ }^{2}$ Department of Geosciences, University of Fribourg, Fribourg, Switzerland

${ }^{3}$ Institute of Geography and Oeschger Centre for Climate Change Research, University of Berne, Bern, Switzerland

${ }^{4}$ Centre for Development and Environment, University of Berne, Bern, Switzerland

Conflict of interest: The authors have declared no conflicts of interest for this article.
}

\section{INTRODUCTION}

Water resources management in the 21st century $\checkmark$ is facing great challenges in several parts of the world due to climate change, population growth, and increasing pressure placed on water resources by competing water uses. ${ }^{1,2}$ As the Intergovernmental Panel on Climate Change (IPCC) noted in 2007, the consequences of climate change for water systems include variations in discharge and sediment transfer, changes in the seasonal availability of water 
resources, and impacts on the wider hydrological cycle (rainfall, snow indices, altitude of the snowline, evaporation etc.). ${ }^{3}$ Modeling of future water availability is generally achieved by calculating surface runoff with hydrological models driven by global or regional climate scenarios. ${ }^{3,4}$ Seasonality of flows in snowand glacier-fed rivers will change in the future-most notably with warming leading to more runoff during the cold season-and increased risk of drought in summer and autumn due to an earlier melt period. ${ }^{5-7}$ In rain-dominated catchments, seasonality is increasing with higher flows during peak flow seasons and lower flows during low flow seasons. ${ }^{3,8}$

Water stress (situations when the water demand exceeds the available resource or when poor quality restricts its uses) does not depend only on factors related to climate; socioeconomic changes, population growth, and technological improvements also significantly influence future water needs. Modeling future water demand can be addressed in a simple way through estimating population growth in combination with changes in basic indices of water use per capita $^{1,9}$ or in a more complex fashion by using more or less sophisticated water withdrawal projections. ${ }^{2}$ The assessment of water stress is generally made at the continental, ${ }^{1,2}$ country or large regional basin scales (see Ref 10 for the Mediterranean region; Refs 11, 12 for the Alps; Ref 13 for Europe). In a given regional or national context it is often through local institutions that water use is regulated, making them play a crucial role in determining water demand and hence water stress. At the local scale, one of the key challenges in predicting how the current water systems will evolve in the future is to calculate accurately the current water demand (see Refs 14-16 for demand calculation methodologies used in the Kitzbühel area, Austria) and to take into account these complex local management mechanisms-often characterized by a combination of formal and informal rules for sharing water and/or complex power relations between stakeholders-in modeling studies.

The aim of this article is to assess and compare the possible impacts of climate and socioeconomic changes in the mid-21st century in a small region situated in southwestern Switzerland (Figure 1), and to propose governance recommendations for the decision-makers. This interdisciplinary study was carried out on the territory of 11 municipalities, and aimed at quantifying current and future water availability and needs (blue water balance; see Ref 17 for a discussion). By combining hydrological modeling and cartographic and social science methods, the research aimed to answer three main questions: (1) what changes in water availability and water demand might occur by 2050? (2) how can we assess the impacts of socioeconomic changes on the water use system? (3) is the current and future water management system sustainable? The responses of these questions were based on interactive exchange between the interdisciplinary team of researchers and constant interaction with local stakeholders. In the concluding part, the importance of interdisciplinary and transdisciplinary research and the difficulties in communicating research results to stakeholders are discussed.

\section{STUDY AREA AND METHODS}

\section{Study Area}

The study area-the Crans-Montana-Sierre region-is situated in southwestern Switzerland, in the south-oriented right side of the Rhone river valley (Figure 1). This area is known as the driest region in Switzerland with an annual mean rainfall rate of less than $600 \mathrm{~mm}$ on the valley floor (500 m ASL) and a steep precipitation gradient leading to important water availability at the higher altitudes (more than $2500 \mathrm{~mm}$ per year at $3000 \mathrm{~m}$ ASL), mostly falling as snow during the winter season. The hydrological regime of the various catchments is, therefore, nival to nivo-glacial, and the relatively large Glacier de la Plaine Morte $\left(7.88 \mathrm{~km}^{2}\right.$ in 2011$)$ covers part of the area. ${ }^{18}$ Because of the characteristics of this flat glacier situated on a karstic basement, with waters either draining toward the North (Simme catchment) or to the South (the study area), the contribution of the glacier to runoff in the study area is poorly understood. ${ }^{19}$

The economy is driven by tourism and agriculture (Figure 1). Crans-Montana is one of the largest tourist resorts in Switzerland with more than 40,000 beds, a strong dominance of the winter season (ski), and a relative specialization on golf and hiking activities during the summer season. Agriculture is dominated by wine-growing in the lower parts of the area ( $<800 \mathrm{~m} \mathrm{ASL}$ ), whereas livestock is reducing rapidly. Both vineyards and meadows need irrigation during the summer season, and irrigation is also practiced in the residential zones, around individual houses. ${ }^{20}$ The area was characterized by a strong population growth during the 20th century, with individual housing dominant, except in the city of Sierre.

\section{Methods}

Interdisciplinary research is at the core of the analysis. It was structured around a series of disciplinary substudies (climatology, hydrology, glaciology, water use 


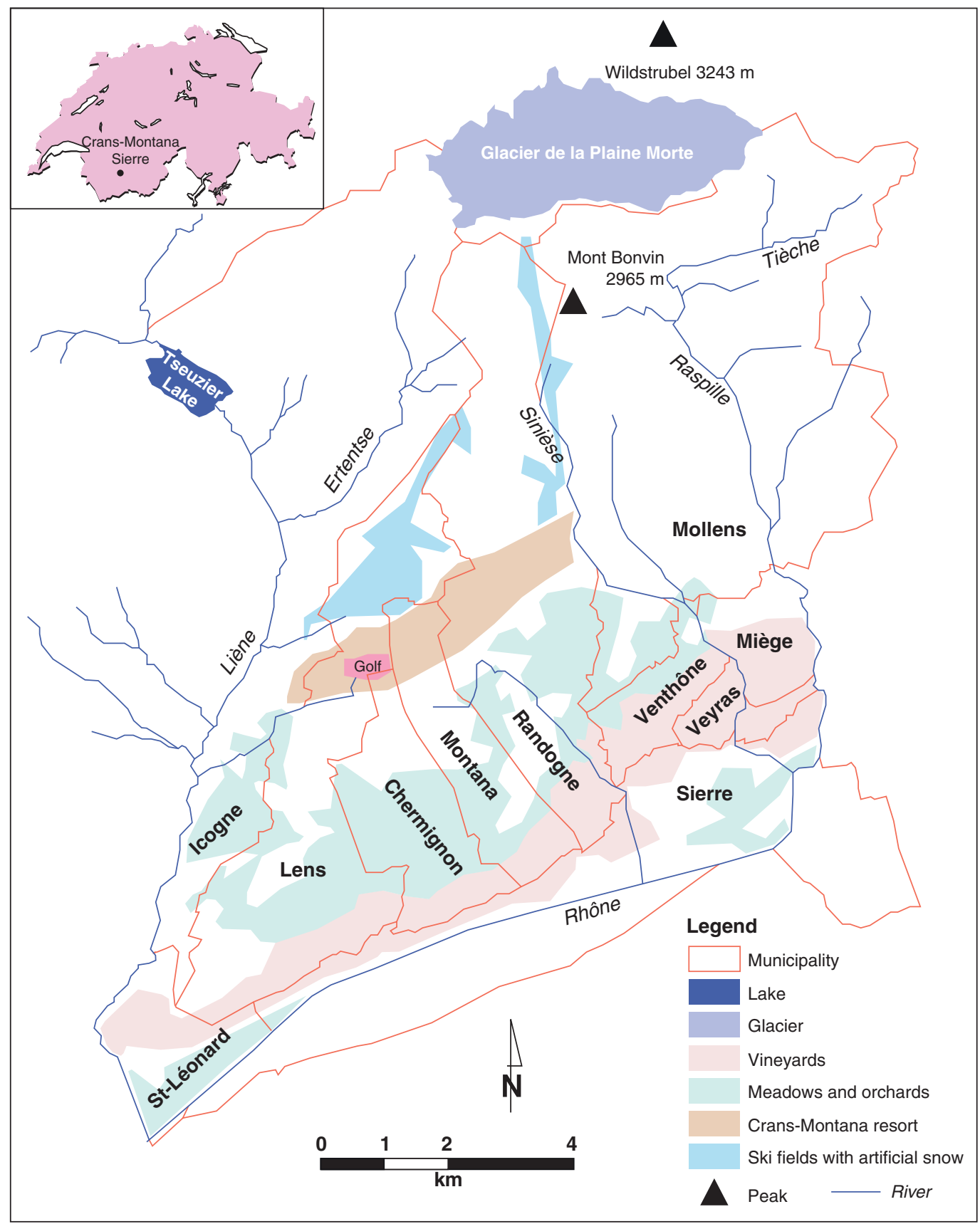

FIGURE 1 | Situation of the study area.

system, and water management analysis), which were linked in a meaningful way. Throughout the research process, in order to deliver the desired interdisciplinarity, project researchers regularly met to exchange knowledge, to discuss and to link their findings, and to come to a joint evaluation of the sustainability of the water management system in place. ${ }^{21,22}$

The first stage was the characterization of the current water system. The hydrological analysis combined: (1) intense measurements in the field by the development of a network of climatological and hydrological stations, and in-depth measurements (e.g., evapotranspiration) in specific places; (2) geophysical surveys applying ground penetrating radar to determine the thickness of Glacier de la Plaine Morte $^{18}$; (3) hydrogeological survey and isotopic and chemical measurements in the Plaine Morte catchment in order to assess the contribution of glacier and snow melt to runoff in the study area ${ }^{19}$; $(4)$ modeling of the 
actual runoff in the headwater basins with the physically based Penn State Integrated Hydrologic Model (PIHM). ${ }^{23}$ A model time step of 1 day was chosen. Elevation and topographic features were extracted from a digital elevation model (DEM) with $10 \mathrm{~m}$ resolution. Precipitation data were derived from the dataset 'Daily precipitation grid for Switzerland 1961-2009', ${ }^{24}$ with about $2 \mathrm{~km}$ resolution. For each catchment, the representative pixels were used to compute daily precipitation gradients according to the corresponding mean elevation. These gradients were then applied to estimate daily precipitation for each element based on their mean elevation. Temperature was derived trough linear regression with altitude from a set of eight meteorological stations. As for precipitation, the estimated daily gradients were then applied to compute daily temperature for each element based on their mean elevation. The scale-independent parameters were established a priori with values obtained from the literature or from site experiments, and extrapolated in space based on stationary catchment attributes (mainly soil and land cover data). To some parameters, such as albedo, Leaf Area Index (LAI) and melt factors, monthly values were assigned according to the seasonal cycle. For the modeling of evapotranspiration and snowmelt in this topographically complex and generally south facing mountainous region, a special focus was put onto the correct modeling of radiation balance. Due to the complex geology ${ }^{19}$ basin, delimitation was undertaken regarding all available information from tracer experiments and from geological profiles.

The water use system was studied, through intense documentary survey in the 11 administrations, in two steps ${ }^{20,25}$ : (1) description and cartography of the four main water use subsystems: hydropower production, domestic uses, irrigation, and tourist uses (artificial snowmaking and golf course irrigation). Immaterial uses (e.g., water landscapes), ecosystem services, and qualitative characteristics were not assessed; and (2) quantification of water needs at the communal and monthly scales. Current management was assessed through: (1) a survey mixing interviews with stakeholders and document review ${ }^{26}$; (2) a qualitative assessment of various criteria of sustainability. ${ }^{22}$

The second stage aimed at predicting future water resource and demand, and to assess changes in sustainability induced by several territorial development scenarios. Change in water management in the future is driven by two groups of factors: hydroclimatic and socioeconomic factors. Change provoked by climate change was addressed by using regional climatic scenarios. ${ }^{27,28}$ The used regional climate change scenario, based on the balanced emission scenario $\mathrm{A} 1 \mathrm{~B}$, indicates an increase in temperature of $1.2^{\circ} \mathrm{C}$ in annual mean for the period 2021-2050 compared to 1980-2009, as for precipitation, changes are estimated to decrease by $6 \%$ in summer [(June-July-August)] and to increase by $5 \%$ in winter [(December-January-February $)]$. To estimate hydrological changes the Glacier Evolution Runoff Model (GERM) ${ }^{29}$ and the hydrological model $\mathrm{PIHM}^{23}$ were used. Regional climatic scenarios were also used to calculate changes for specific water needs, in particular irrigation and artificial snowmaking (see Ref 25 for details).

Changes driven by socioeconomic factors were identified through the co-production of knowledge, ${ }^{30-33}$ leading to four visions of development $^{34}$ (Table 1). The first vision-called growth strategy-considers that economic growth, based on mass tourism and built areas extension, is at the core of regional development. Agriculture continues to loose importance in the regional economy, and the population rapidly increases in the next decades. Two subscenarios (1a and $1 \mathrm{~b})$ consider different demographic increase rates. It is a kind of business-as-usual scenario, and in this vision, water issues are considered to be easily managed using technical measures. In the second vision (stabilization strategy), water is considered as one of the most important resources at the regional scale, and management is focused on optimizing water consumption (water demand management). In this vision, agriculture remains a core economic activity and therefore irrigation needs are thought to increase under a changing climate. The moderation strategy (vision 3) aims at improving the quality of life for residents and visitors, and individual measures for managing water are promoted. Finally, in the fourth vision-developed by the local stakeholders and considered as a shared vision of future development-economic growth is balanced by social needs (equity between citizens) and ecological considerations.

These visions were then translated into changes in the land use system in response to climate change (e.g., a rise in elevation of $100 \mathrm{~m}$ of the upper limit of vineyards due to warming in vision 2; reduction of irrigated surfaces in some scenarios; abandonment of artificial snow production in vision 3, etc.). Finally, future water demand was calculated for each vision, and compared with the current water use situation. ${ }^{25}$ The evolution of the sustainability of water management was also assessed by an expert evaluation of the changes in each of the sustainability criteria used for the assessment of the current management. ${ }^{22}$ This 
TABLE 1 | Main Characteristics of the Four Visions of Regional Development (after Ref ${ }^{34}$, simplified)

\begin{tabular}{|c|c|c|c|c|}
\hline Topic & $\begin{array}{c}\text { Vision 1: } \\
\text { Growth Strategy }\end{array}$ & $\begin{array}{c}\text { Vision 2: } \\
\text { Stabilization Strategy }\end{array}$ & $\begin{array}{c}\text { Vision 3: } \\
\text { Moderation Strategy }\end{array}$ & $\begin{array}{c}\text { Vision 4: } \\
\text { Stakeholder's Shared Strategy }\end{array}$ \\
\hline Demography & Strong population growth & Slight population growth & Population decrease & Slight population growth \\
\hline Water consumption & $\begin{array}{l}\text { No water-saving efforts } \\
\text { Drinking water at times } \\
\text { used for irrigation }\end{array}$ & $\begin{array}{l}\text { Water supply more efficient } \\
\text { Separate drinking water and } \\
\text { irrigation water networks }\end{array}$ & $\begin{array}{l}\text { Water supply more efficient } \\
\text { Separate drinking water and } \\
\text { irrigation water networks } \\
\text { Great efforts to save water }\end{array}$ & $\begin{array}{l}\text { Water supply has become more } \\
\text { efficient } \\
\text { Separate drinking water and } \\
\text { irrigation water networks }\end{array}$ \\
\hline Spatial planning & $\begin{array}{l}\text { Unrestrained building } \\
\text { activities (under current } \\
\text { legislation) }\end{array}$ & $\begin{array}{l}\text { Densification } \\
\text { Construction of second homes } \\
\text { restricted } \\
\text { Construction of small } \\
\text { apartment buildings } \\
\text { encouraged }\end{array}$ & $\begin{array}{l}\text { Building industry developed } \\
\text { into reconstruction and } \\
\text { energy-efficient renovation } \\
\text { industry } \\
\text { Some previous building areas } \\
\text { rezoned as 'non- } \\
\text { developable' areas }\end{array}$ & $\begin{array}{l}\text { Densification } \\
\text { Construction of second homes } \\
\text { restricted } \\
\text { Construction of small } \\
\text { apartment buildings } \\
\text { encouraged }\end{array}$ \\
\hline Tourism & $\begin{array}{l}\text { Mass tourism based mainly } \\
\text { on skiing and golf (new } \\
\text { snow cannons and golf } \\
\text { greens) }\end{array}$ & $\begin{array}{l}\text { Tourism more attractive all year } \\
\text { round } \\
\text { Skiing areas reduced }\end{array}$ & $\begin{array}{l}\text { Tourism industry focused on } \\
\text { 'soft' tourism }\end{array}$ & $\begin{array}{l}\text { Tourism more attractive all year } \\
\text { round } \\
\text { Skiing area reduced }\end{array}$ \\
\hline Agriculture & $\begin{array}{l}\text { Agriculture not a priority } \\
\text { Extensive farming }\end{array}$ & $\begin{array}{l}\text { Agriculture playing an } \\
\text { important role in food } \\
\text { production (especially meat) }\end{array}$ & $\begin{array}{l}\text { High priority agriculture } \\
\text { primarily serving tourism, } \\
\text { nature conservation, and } \\
\text { landscape maintenance }\end{array}$ & $\begin{array}{l}\text { High priority agriculture } \\
\text { primarily serving tourism, } \\
\text { nature conservation, and } \\
\text { landscape maintenance }\end{array}$ \\
\hline Viticulture & $\begin{array}{l}\text { Intensive viticulture } \\
\quad \text { (increased profitability) } \\
\text { Sprinkler irrigation }\end{array}$ & $\begin{array}{l}\text { Viticulture continuing at same } \\
\text { level of intensity } \\
\text { (high-quality wine) } \\
\text { Drip irrigation }\end{array}$ & $\begin{array}{l}\text { Extensive viticulture } \\
\text { (high-quality wine and } \\
\text { biodiversity) } \\
\text { Drip irrigation }\end{array}$ & $\begin{array}{l}\text { Viticulture continuing at same } \\
\text { level of intensity } \\
\text { (high-quality wine) } \\
\text { Drip irrigation }\end{array}$ \\
\hline Hydropower & $\begin{array}{l}\text { Hydropower production: } \\
\text { high priority } \\
\text { All rivers' hydropower } \\
\text { potentials fully tapped }\end{array}$ & $\begin{array}{l}\text { Hydropower production: high } \\
\text { priority, but other water } \\
\text { needs considered equally } \\
\text { important (irrigation, } \\
\text { domestic uses, etc.) }\end{array}$ & $\begin{array}{l}\text { Hydropower production: } \\
\text { important, but aim to reduce } \\
\text { energy consumption and } \\
\text { diversify energy sources }\end{array}$ & $\begin{array}{l}\text { Hydropower production: } \\
\text { important, but aim to reduce } \\
\text { energy consumption and } \\
\text { diversify energy sources }\end{array}$ \\
\hline Nature & $\begin{array}{l}\text { Legal minimum residual } \\
\text { flow lowered }\end{array}$ & $\begin{array}{l}\text { Legal minimum residual flow } \\
\text { remaining the same }\end{array}$ & $\begin{array}{l}\text { Legal minimal residual } \\
\text { increased }\end{array}$ & $\begin{array}{l}\text { Legal minimum residual flow } \\
\text { remaining the same }\end{array}$ \\
\hline $\begin{array}{l}\text { Water } \\
\quad \text { infrastructure }\end{array}$ & $\begin{array}{l}\text { Water infrastructure } \\
\text { networks expanded }\end{array}$ & $\begin{array}{l}\text { Unified network for drinking } \\
\text { water }\end{array}$ & $\begin{array}{l}\text { Unified network for drinking } \\
\text { water } \\
\text { Households harvest and store } \\
\quad \text { rainwater locally }\end{array}$ & $\begin{array}{l}\text { Unified network for drinking } \\
\text { water } \\
\text { Households harvest and store } \\
\quad \text { rainwater locally }\end{array}$ \\
\hline $\begin{array}{r}\text { Institutions and } \\
\text { collaboration }\end{array}$ & $\begin{array}{l}\text { Intercommunal } \\
\text { collaboration remaining } \\
\text { the same } \\
\text { Water rights intact } \\
\text { Water pricing based on } \\
\quad \text { flat rate }\end{array}$ & $\begin{array}{l}\text { Intercommunal collaboration } \\
\text { improved and water supply } \\
\text { management centralized } \\
\text { Water rights renegotiated } \\
\text { Water pricing based on } \\
\text { consumption }\end{array}$ & $\begin{array}{l}\text { Water management by a joint } \\
\text { association that ensures } \\
\text { water supply for the benefit } \\
\text { of all inhabitants of the } \\
\text { region } \\
\text { Water pricing based on } \\
\text { consumption (graded } \\
\text { system) }\end{array}$ & $\begin{array}{l}\text { Water management by a joint } \\
\text { association that ensures } \\
\text { water supply for the benefit } \\
\text { of all inhabitants of the } \\
\text { region } \\
\text { Water pricing based on } \\
\text { consumption (graded } \\
\text { system) }\end{array}$ \\
\hline
\end{tabular}

evaluation allowed us to show which scenarios would tend to more or less sustainability.

\section{RESULTS}

\section{Water Resource}

The Glacier de la Plaine Morte represents an important local long-term water reservoir. At present, the glacier has a maximum thickness of more than $200 \mathrm{~m}$ and an ice volume of about $0.8 \mathrm{~km}^{3} \cdot{ }^{18}$ Dye tracing of glacial melt water indicates that a significant fraction of glacier runoff is linked to the Crans-Montana-Sierre region over karstic pathways, although the glacier is entirely located north of the main water divide. ${ }^{19}$ To calculate future changes in glacier mass balance, area, ice volume, and discharge, the glacio-hydrological model GERM ${ }^{29}$ was applied. The model is calibrated 

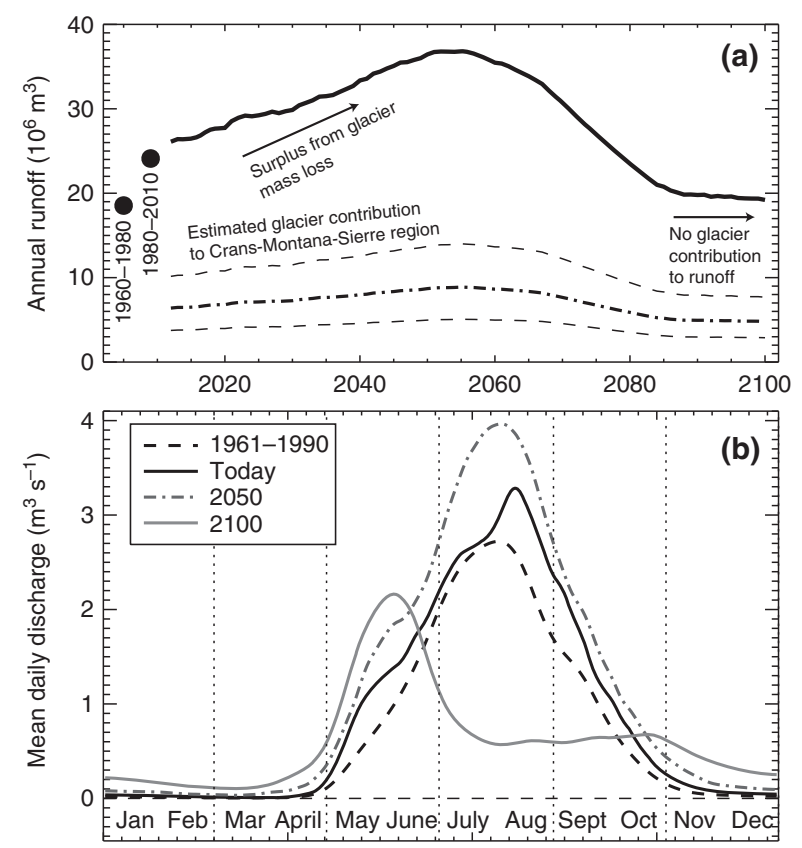

FIG URE 2 | Modeled future runoff from the basin of Glacier de la Plaine Morte using the median climate evolution given by Regional Climate Models (RCMs). (a) Annual runoff from the entire glacier and estimated contribution to the South (eastern Crans-Montana-Sierre region) including uncertainty ranges. Mean runoff for two periods in the past is indicated. (b) Averaged daily runoff hydrographs for four periods between 1960 and 2100.

on in situ field data ${ }^{18}$ and is forced with Regional Climate Model (RCM) results. ${ }^{27}$

Strong glacier mass loss is expected over the next decades being amplified by several positive feedback effects. The model indicates a complete disappearance of the Glacier de la Plaine Morte by about 2080. Owing to increased glacier melt and thus release of water from long-term glacial storage, higher glacier runoff is likely until 2050 (Figure 2). Toward the end of the century the glacier can however no longer provide additional melt water resulting in decreasing annual runoff, as well as a dramatic reduction during the summer months (Figure 2(b)). Future changes in glacier supply to karstic springs feeding mainly the eastern Crans-Montana-Sierre region are highly uncertain but are expected to follow the same trends as the overall glacier discharge (Figure 2(a)).

In the headwater regions, strong altitudinal and east-west precipitation gradients are observed with maximum precipitation of about $1600 \mathrm{~mm}$ per year in the eastern and up to $4000 \mathrm{~mm}$ per year in the western observation stations. Runoff shows a distinct seasonal variation with minimum flow from December to March, a steep increase in April and maximum flow from May to August (Figure 3). Interannual variations are large as well, with deviation of about \pm 25 to
$30 \%$ in wet/dry years compared to average years or summer seasons (Figure 3). A total volume of about 140 million $\mathrm{m}^{3}$ of water per year is available in the headwaters of the study region.

Climate change scenarios ${ }^{27,28}$ were used to calculate water resource availability in the future. By 2040 a slight increase (\%) of water flows in summer is estimated, due to further increase of melt water from the glacier; in winter an increase of $7 \%$ (at the minimum) is estimated due to an increase in liquid precipitation and in the minimum altitude at which snow falls. Seasonal distribution of mean water resources is expected to change slightly to an earlier seasonal peak (May instead of June) and with slightly less water in late summer and autumn (Figure 3). Moreover, hotter and drier summers should more frequently be observed in future. ${ }^{35}$ Regarding the second part of the 21 st century the total amount of available water in summer will certainly decrease, due to the vanishing glacier and a stronger decrease of summer precipitation. First estimates show a water availability decrease of about $-15 \%$ in the Tseuzier catchment $(-20$ to $-30 \%$ in May).

\section{Water Management}

The structure of water use management is characterized by a high degree of complexity due to the following factors ${ }^{20}:(1)$ the institutional fragmentation into 11 municipalities, whose delimitations do not coincide with hydrological limits, and the altitudinal stratification of economic activities ${ }^{36}$; $(2)$ the historical development of the region, in particular various phases of development of the tourist resort, ${ }^{37}$ which required the construction of important water transfer and storage infrastructures; (3) the presence of a large tourist resort that induces important peaks in water demand during some periods of the year, and influences some specific water uses related to tourism (irrigation of golf courses, artificial snow production). For all these reasons, the infrastructure networks are complex and not fully interconnected, and the water use system-and therefore the water demand-varies from one commune to the other (Figure 4). Irrigation is a particularly complex water use that has been difficult to assess for the following reasons. Four kinds of surfaces are irrigated: meadows, vineyards, golf courses, and gardens/lawns (in the residential zones). Irrigation of meadows and vineyards is performed by using a historical network of channels-called bisses - which have existed since the Middle Ages and have been managed by common-pool associations of irrigators called consortages. Today the irrigation system is a complex combination of public and common management, characterized by many informal arrangements. 


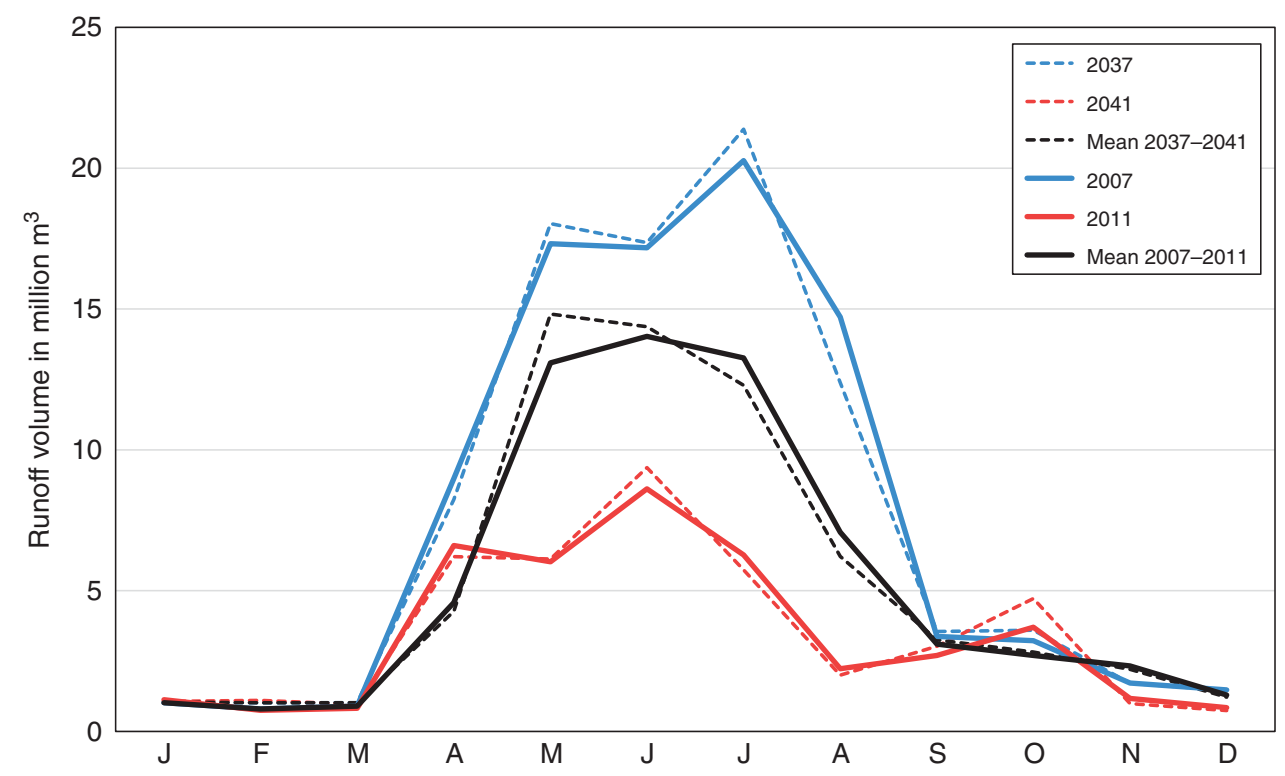

FIG URE 3 | Annual water resources distribution for the wet year 2007, the dry year 2011, and for the mean annual values (2007-2011) in the eastern headwater region (Ertense to Tièche river), which is most important for the water supply of the Crans-Montana-Sierre region. The dotted lines are the projections for the near future around 2040.

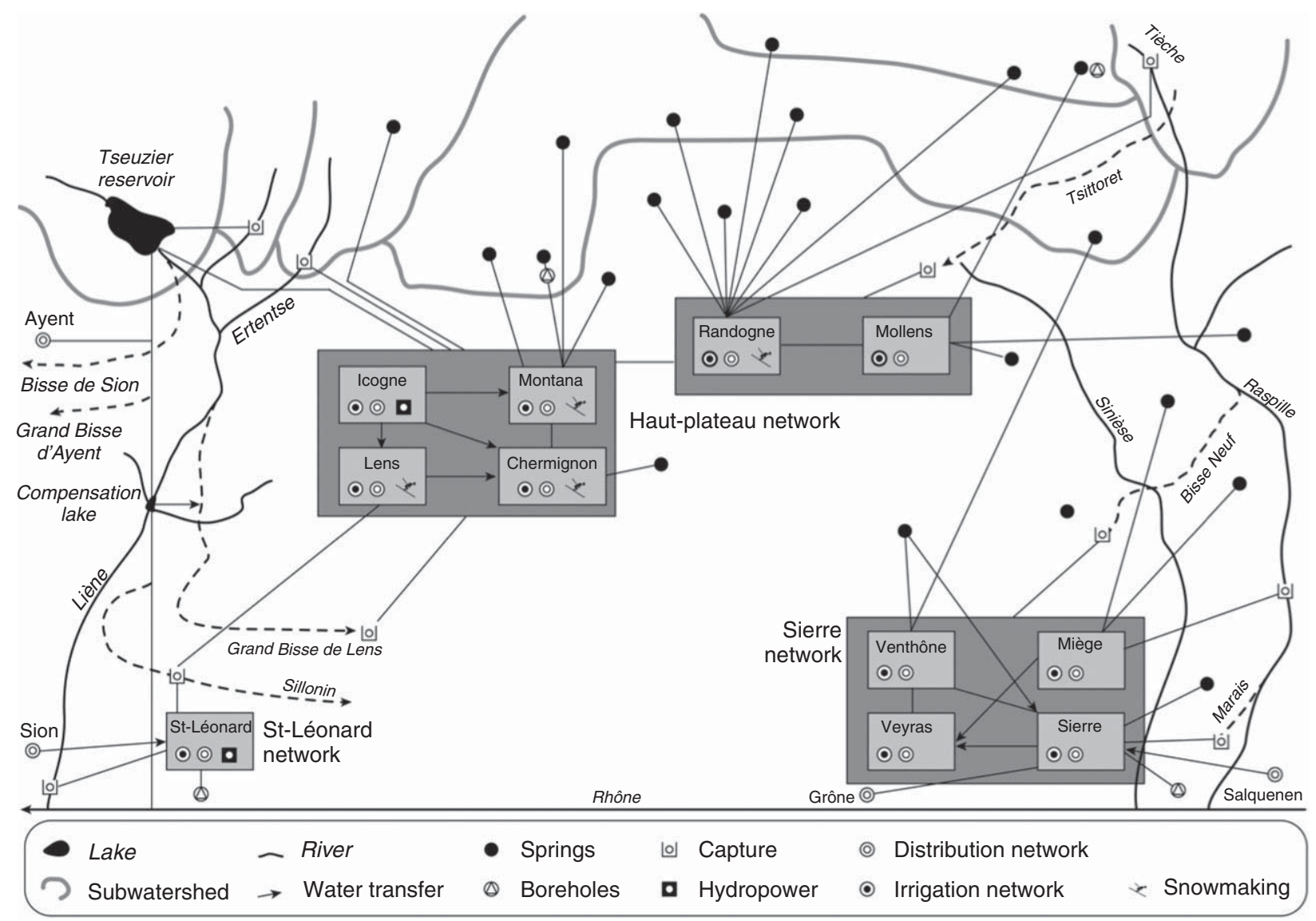

FIG URE 4 | The complexity of the regional water system. Municipalities have quite different water 'profiles' and supply networks are not fully interconnected. 
Irrigation in the residential zones varies from one commune to the other: in some parts of the study area water distributed as drinking water is largely used for the irrigation of gardens and lawns, whereas in other parts, parallel supply infrastructures (for drinking water and for irrigation) have been developed. Two specific uses related to tourism have developed during the last decades: first, irrigation of the three golf courses due to dry climatic conditions in summer time, and secondly, since the end of the 1980s, artificial snow production. Finally, as in most Alpine valleys, hydropower production is one of the major water use systems in the area. Only one catchment (the Liène river) has been equipped since the mid-20th century, and today the Tseuzier reservoir $\left(51\right.$ million $\left.\mathrm{m}^{3}\right)$ is also used for storing water for drinking, irrigation, and artificial snowmaking.

Hydropower production demands the largest volumes of water $(88.5 \%$ of the total water used in 2010). The other uses (irrigation, domestic uses, artificial snowmaking) accounted 10.5 million $\mathrm{m}^{3}$ in 2010 and 13.6 million $\mathrm{m}^{3}$ in 2011 , that is less than $10 \%$ of the annual volume of resources (140 million $\mathrm{m}^{3}$ ). On the annual scale (Figure 5), domestic use is the largest use (after hydroelectricity), with a total demand reaching nearly 8 million $\mathrm{m}^{3} ; 1 / 8$ of these volumes are in fact used for the irrigation of gardens and lawns. ${ }^{20}$ Water needs for irrigation vary according to the climatic conditions. Two groups of years are visible: relatively wet years (e.g., 2010), with needs reaching 4-5 million $\mathrm{m}^{3}$, and dry years (e.g., 2011), with average needs exceeding 9 million $\mathrm{m}^{3}$. Water needs and water supply are, therefore, anticorrelated, with maximum needs in dry years that correspond to years with minimum supply. Water needs for the production of snow and for the irrigation of golf courses are seasonal and not very important at the regional scale. Nevertheless, artificial snow production occurs during the period of low flows and requires, therefore, water storage capacity.

Supply management, legal fuzziness, and institutional complexity dominate today's water governance in the study area. Historically, potential problems of availability and distribution of water have been tackled by searching and transporting water from increasing distances to the places of consumption. ${ }^{36,38}$ Thus, conflicts of interests and competition between different users and usages have been countered and regulated through the depletion of the resource at the cost of high infrastructure investments and the ecological needs. This logic of supply management is still dominant, even if first indications show an increasing interest of authorities to intervene in managing water demand.

The situation of water rights can be summarized as extremely fuzzy. A multitude of rights (for irrigation but also between municipalities or landowner associations) are not defined in written documents. Actors are thus referring to rights, contracts or agreements, to which all stakeholders comply, but no overview and clarity of the legal situation is accessible in order to render transparency. The problem here is the difficulty of creating a comprehensible basis for the (re)negotiation of certain use or property rights toward more equity between users. Nevertheless, a rather positive feature is that the system is quite flexible and easily adapting to face local water stress situations. ${ }^{26,37}$

The legal fuzziness is also due to a multilayered density of institutions with different rights, authority or responsibility over different types of water. The legal, political, and economic relationships that exist among different stakeholders, such as local authorities, irrigation channel associations, landowner associations, a hydropower company, winter resort enterprise, and tourism association, are multiple and complex. Negotiations and bilateral or

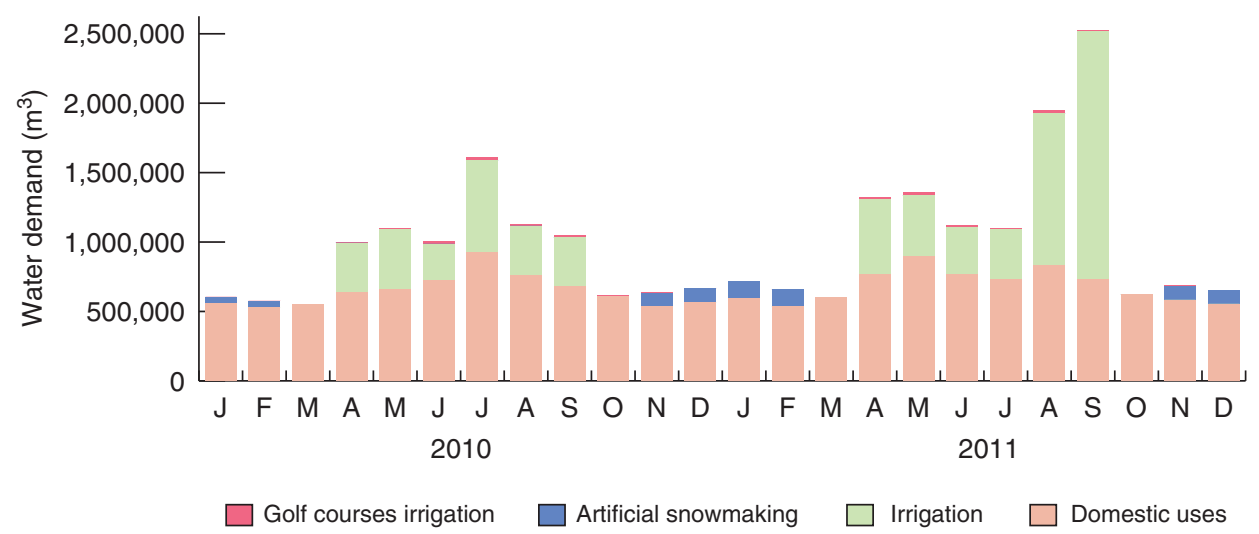

FIG URE 5 | Today's water demand (in $\mathrm{m}^{3}$ ) during a 'normal' year (2010) and a dry year (2011). Hydropower production is not considered. 
TABLE 2 | Today's Water Needs in the Crans-Montana-Sierre Region (in million $\mathrm{m}^{3}$ ), and Future Water Needs According to the Four Visions for Regional Development (Deviation in \% from a Normal Year). In Brackets, Maximum Needs in Dry Years

\begin{tabular}{|c|c|c|c|c|c|c|}
\hline & $\begin{array}{l}\text { Domestic } \\
\text { Uses }\end{array}$ & Irrigation & $\begin{array}{c}\text { Golf Courses } \\
\text { Irrigation }\end{array}$ & $\begin{array}{c}\text { Artificial } \\
\text { Snowmaking }\end{array}$ & $\begin{array}{l}\text { Total (in Brackets, } \\
\text { Maximum Needs) }\end{array}$ & $\begin{array}{l}\text { Hydropower } \\
\text { Production }\end{array}$ \\
\hline 2010_normal year & 7.7 & 2.4 & 0.08 & 0.3 & 10.5 & 67.5 \\
\hline 2011—dry year & 8.2 & 4.8 & 0.09 & 0.45 & 13.6 & 61.2 \\
\hline $\begin{array}{l}\text { Future water needs } \\
\text { Vision } 1 \mathrm{a}\end{array}$ & $+33.5 \%$ & $-18.7 \%$ & $+7.8 \%$ & $+77 \%$ & $+24 \%(+59 \%)$ & $?$ \\
\hline $\begin{array}{l}\text { Future water needs } \\
\text { Vision } 1 \mathrm{~b}\end{array}$ & $+23.1 \%$ & $-24.8 \%$ & $+7.8 \%$ & $+77 \%$ & $+24 \%(+48 \%)$ & $?$ \\
\hline $\begin{array}{l}\text { Future water needs } \\
\quad \text { Vision } 2\end{array}$ & $+7.6 \%$ & $+32.6 \%$ & $+14.5 \%$ & $-19 \%$ & $+19 \%(+60 \%)$ & $?$ \\
\hline $\begin{array}{l}\text { Future water needs } \\
\quad \text { Vision } 3\end{array}$ & $-9.6 /-16.8 \%$ & $-34 \%$ & $+6.8 \%$ & $-100 \%$ & $-13 \%(+18 \%)$ & $?$ \\
\hline $\begin{array}{l}\text { Future water needs } \\
\text { Vision } 4 \text { (stakeholders) }\end{array}$ & $+7.6 \%$ & $-0.2 \%$ & $+5.8 \%$ & $-19 \%$ & $-3 \%(+49 \%)$ & $?$ \\
\hline
\end{tabular}

multilateral agreements on the level of technicians or political authorities ${ }^{38}$ render the management situations rather opaque for outsiders and fully democratic decision-making processes are not present.

\section{Water Stress}

The calculation of water resources and water demands shows that there is no water stress at the moment at the annual scale. ${ }^{20}$ The estimation of future water uses around 2050 was performed by combining the use of

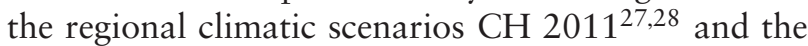
four developed visions. ${ }^{25}$ Regional climatic changes were important to consider due to their impacts on some water needs such as irrigation (increased temperature and evapotranspiration; decreased summer rainfall) or artificial snowmaking (elevation of the natural snowline). As stated above each development vision was translated into changes in land use. Both mean and maximum needs (in dry years) were calculated.

Results show a rather large spectrum (from -13 to $+24 \%$ ) of water need changes according to the various regional development strategies (Table 2), which are much higher than the changes in water availability $(+1 \%$ in summer, $+6 \%$ in winter $)$ due to climate change. Visions 1 and 2 clearly increase the water demand, whereas visions 3 and 4 reduce the water demand mainly because of the decrease in water needs for irrigation-due to technical and institutional improvements-and the transition toward 'soft' tourism. Local authorities should, therefore, choose a development strategy ( 3 or 4 ) that lowers the impact on water needs; this kind of strategy needs dramatic changes in the regional development and land planning policy.
It seems that even in the business-as-usual scenario the annual mean water stress will only moderately increase by the mid-21st century because of the slight increase in the water resource and of the current low rate of water demand $(<10 \%)$ in relation to the resource. It could be argued that no change in the current practice is required. Nevertheless, in dry years each development scenario shows an increase in the annual water demand (around $+60 \%$ in visions 1 and $2,+18 \%$ in vision 3 , and $+49 \%$ in vision 4 ; Table 3). This means that even if the annual mean water stress will not increase dramatically, situations of water stress will occur in dry years, because of the interannual climate variations, especially in visions 1 and 2. Moreover, modeling of the water availability and water demand at the monthly scale ${ }^{39}$ shows two periods of water stress: in winter (January-March), that is already the case due to low river and spring flows in winter and high water demand in the tourist resort of Crans-Montana; in the second part of summer (August-September). Increasing water stress in this second period is clearly a new trend and is related to the changes in the hydrological regimes of rivers (shift of flow peaks into the first part of the summer), the decrease of summer rainfall rates, and the increase of evapotranspiration due to temperature elevation, but also to the increase of water needs, especially for irrigation. Again, the local water stress at the monthly scale is estimated as higher in visions 1 and 2 than in visions 4 and 3 .

\section{Water Sustainability}

Sustainable water management systems should allow the current generations to meet their societal goals in 
TABLE 3 | Overview on the Sustainability Principles and Their Assessment

\begin{tabular}{|c|c|c|c|c|c|c|}
\hline Principles & Subprinciples/Indicators & Present & Vision 1 & Vision 2 & Vision 3 & Vision 4 \\
\hline \multirow[t]{4}{*}{ Regional development } & Basic needs & Good & Moderate & Good & Very good & Very good \\
\hline & Recreation and enjoyment & Good & Moderate & Good & Good & Very good \\
\hline & Agriculture & Moderate & Poor & Moderate & Poor & Good \\
\hline & Hydropower production & Good & Very good & Very good & Good & Very good \\
\hline \multirow[t]{4}{*}{ Ecological integrity } & Groundwater quantity & Very good & Very good & Very good & Very good & Very good \\
\hline & Surface water quantity & Very poor & Poor & Good & Very good & Good \\
\hline & Water quality & Good & Good & Good & Good & Good \\
\hline & Benefits (and harms) of water use & - & - & - & - & - \\
\hline \multirow[t]{3}{*}{ Justice } & Distributive justice & Poor & Very poor & Moderate & Good & Moderate \\
\hline & Procedural justice & Moderate & Moderate & Good & Good & Good \\
\hline & Contextual justice/recognition & Poor & Poor & Moderate & Good & Moderate \\
\hline \multirow[t]{5}{*}{ Adaptive capacity } & Material and financial capital & Good & Very good & Very good & Very good & Very good \\
\hline & Collaborative capacity & Moderate & Poor & Good & Very good & Good \\
\hline & Institutions and entitlements & Moderate & Poor & Good & Very good & - \\
\hline & Resource efficiency & Poor & Very poor & Good & Very good & Good \\
\hline & Learning capacity & Poor & - & - & - & - \\
\hline
\end{tabular}

an equitable way while at the same time maintaining the options of the future generations to live the life they value. ${ }^{40}$ This means that water management systems can be regarded as sustainable when they contribute to the societal goals of regional development, maintain the ecological and hydrological integrity, respect issues of social and environmental justice, and have a high degree of adaptive capacity. ${ }^{22,34}$

In order to assess the mentioned dimensions of sustainable water management, each of the four mentioned principles was divided into a set of subprinciples (Table 3). Subsequently, all those principles were evaluated taking into account the totality of available research results. ${ }^{22}$

The sustainability assessment revealed that the present water management system of CransMontana-Sierre generally enables the societies to develop their region in a desired way. It allows fulfilling basic domestic water needs, and use of water for economic purposes such as agriculture, tourism, and hydropower as well as recreation and enjoyment. The sustainability of agriculture is rated a bit lower as in dry years water shortage can become a serious problem for agricultural irrigation. ${ }^{20,25}$ However, justice issues are a major concern when a real sustainability assessment has to be made ${ }^{41}$ : costs and benefits of water are very unequally distributed, decision-making processes are not always transparent and there is no organization or platform allowing all affected stakeholders and municipalities to reflect and coordinate on regional dimensions of water governance. Moreover, the stakeholders' capability to access water is very unequal. ${ }^{26}$ The ecological and hydrological integrity as well as the adaptive capacity were both rated as medium. While the quality and quantity of groundwater is regarded as good to very good, the quantities of surface water are thought to be insufficient mainly due to the widespread reflectance of residual water. The adaptive capacity is generally rather strong regarding retrospective adaptation, but weak when it is about more proactive and foresighted solutions. ${ }^{26}$

The assessment of the different future visions provided very heterogeneous results. ${ }^{22}$ Vision 1 leads to a clear decline of the overall sustainability mainly due to increased water demands coupled with unwillingness of institutional reforms such as improved collaboration or clarification and renegotiation of water rights. Visions 2 and 4 lead to an increase and vision 3 to a strong increase of the overall sustainability. Although the final rating of these three visions is rather similar, the underlying reasons are very different. For example, while vision 4 expects a much more extensive infrastructure development than vision 3 , the latter is generally assessed as more positive as the general water demand is lower due to fundamental institutional reforms (not considered in vision 4). Thus, the differences in the assessment of the four visions are the result of the vision's distinct assumptions regarding the following three factors: regional development 
and its water demands, infrastructure development as well as institutional reforms. It is the interplay of these three factors, which accounts for the differences in the assessment. However, as the in-depth assessment showed, the institutional reforms are of particular importance, as without them, also extensive infrastructure developments may not unfold their potential.

\section{DISCUSSION AND CONCLUSION}

\section{Interdisciplinary Research}

Modeling of future water systems is usually based on quite simple assumptions concerning future water demand (e.g., population changes). Nevertheless, as current water systems are usually very complex, with multiple competing uses, multiple groups of actors, and sophisticated formal and informal rules, the estimation of the future water demand needs to take into account this complexity. An interdisciplinary approach-as with the one used in this research-helps developing scenarios concerning future water management. Field measurements (e.g., river flows, hydrogeological measurements) and physical modeling (glaciological, hydrological) helped researchers and local stakeholders to understand the functioning of their water system; these data also allowed us to answer crucial questions such as the date of the glacier disappearance or the volume of future water resource. On the other hand, numerous meetings with the local stakeholders throughout the research (3 years) allowed us to understand the importance of informal rules in the today's water management and to propose several scenarios for future regional development in the studied area. The discussion with the stakeholders of three scenarios-that were elaborated by the researchers on the basis of ideas provided by local actors-resulted in the elaboration of a fourth scenario, viewed by the stakeholders as their common vision for the future. These four visions were then at the core of the modeling phase of the future water demand ${ }^{25}$ and therefore participated to the elaboration of an important part of the results of the research. Finally, inside the research team, interdisciplinary (between natural and social sciences) analyses were very successful in the assessment of the sustainability of current and future water systems. $^{22}$

\section{Governance Messages}

This study not only aimed at analyzing the regional water system, but also at proposing options for more sustainable water management to the stakeholders.
Based on the above summarized information, five key messages were formulated:

1. The socioeconomic changes have a greater impact than climate change on the water system in 2050 .

2. The water quantities available now and in 2050 are generally sufficient. However, shortages are possible in some areas and seasonally.

3. Moving toward more sustainable management requires complementing local water management by a regional platform and coordination.

4. Intermunicipality development of infrastructure can help ensure sustainable water supply, but only if infrastructure is integrated into ambitious institutional reforms.

5. To achieve a sustainable regional water management, improved data management and transparency is needed.

These messages were communicated to the stakeholders and to the regional and national media. Even if most of the messages pointed to the necessity to take measures to improve water management at the regional scale, and therefore pushed the stakeholders to be active, it appears that the stakeholders heard mainly one message: the fact that water quantities will remain sufficient in 2050 to satisfy most of the needs. However, the message was ambivalent: while there should be few problems at the annual average scale, this is not the case between years or within years. Hence, the biggest challenge was not obtaining a robust assessment, but how to communicate it and translate it into actions (both, due to the ambivalent message and the stakeholders' perception and (un)willingness). Thus, the question was not only about producing knowledge, but how to facilitate learning.

A second problem was the time scale. For the climatic and hydrological processes, the mid-century horizon shows few changes, and in this case study an increase of the annual resource due to glacier melting is predicted, whereas it is clear that the situation will deteriorate from 2060 onwards. On the other hand, modeling the regional situation at a 40-year horizon was ambitious due to several uncertainties (economic and political changes), and estimating the region's shape in the second part of the 21st century was not realistic. Again, we were facing the problem of the ambivalent message that climate change will have moderate impacts in 2050 but high impacts in the distant time horizon toward 2100. However, if nothing is done now (business-as-usual), serious 
management problems will arise in the second part of the 21st century. For that reason, at the same time management changes were recommended. For the stakeholders there was, therefore, the question of the need to change if there are few problems in the next 40 years, longer than the life time typical of their jurisdiction.

A third point was the role of the visions. Our results demonstrated which scenarios were better adapted in terms of water demand and water management sustainability, but the key issue was to make the best scenarios adopted by the decision-makers. In this sense, the co-construction of the visions, and the elaboration by the stakeholders of their shared vision, should help them to initiate governance reforms.

\section{Conclusion}

The in-depth interdisciplinary and transdisciplinary research carried out in the Crans-Montana-Sierre region allowed us to answer the question how the water systems might evolve by the 2050 horizon, and to highlight the factors responsible for the variations in water availability and water demand. An interdisciplinary and transdisciplinary approach was favored, both in the research team (specialists of natural and social sciences) and by the collaboration with a group of stakeholders that helped understanding the complexity of the current water management. Four visions of regional development co-produced by the researchers and the stakeholder group were 'translated' according to their impacts on the future water demand. They highlighted the fact that socioeconomic drivers will matter more than climate factors in the future water stress in the area. The results could be formulated into five key messages showing that although few problems are to be expected by 2050 , governance reforms must be undertaken now to improve regional water management sustainability and to avoid acute management problems in the second part of the $21 \mathrm{st}$ century.

This research highlights the fact that modeling of the future water management at the regional scale must take into account the complexity of both natural and social aspects of the current water system in the modeling procedure. Interdisciplinary research and co-production of results with stakeholders are prerequisites to address this issue.

\section{ACKNOWLEDGMENTS}

This project was carried out within the Swiss National Research Program 61 'Sustainable Water Resources Management' (www.nrp61.ch), project 406140-125964. The authors would like to thank the group of local stakeholders for their active participation in the elaboration of scenarios, the local administrations for supplying information, two anonymous referees for valuable comments that improved the manuscript, and Stuart Lane for the edition of the manuscript.

\section{REFERENCES}

1. Vörösmarty CJ, Green P, Salisbury J, Lammers RB. Global water resources: vulnerability from climate change and population growth. Science 2000, 289:284-288.

2. Alcamo J, Florke M, Marker M. Future long-term changes in global water resources driven by socio-economic and climatic changes. Hydrol Sci J 2007, 52:247-275.

3. Kundzewicz ZW, Mata LJ, Arnel NW, Döll P, Kabat P, Jiménez B, Miller KA, Oki T, Sen Z, Shiklomanov IA. Freshwater resources and their management. In: Parry ML, Canziani OF, Palutikof JP, van der Linden PJ, Hanson CE, eds. Climate Change 2007: Impacts, Adaptation and Vulnerability. Contribution of Working Group II to the Fourth Assessment Report of the Intergovernmental Panel on Climate Change. Cambridge: Cambridge University Press; 2007, 173-210.
4. Lehner B, Döll P, Alcamo J, Henrichs T, Kaspar F. Estimating the impact of global change on flood and drought risks in Europe: a continental, integrated analysis. Clim Change 2006, 75:273-299.

5. Barnett TP, Adam JC, Lettenmaier DP. Potential impacts of a warming climate on water availability in snow-dominated regions. Nature 2005, 438:303-309.

6. Zierl B, Bugmann H. Global change impacts on hydrological processes in Alpine catchments. Water Resour Res 2005, 41:W02028. doi: 10.1029/2004WR003447.

7. Köplin N, Schädler B, Viviroli D, Weingartner R. Relating climate change signals and physiographic catchment properties to clustered hydrological response types. Hydrol Earth Syst Sci 2012, 16:2267-2283. doi: 10.5194/hess-16-2267-2012.

8. Köplin N, Schädler B, Viviroli D, Weingartner R. Seasonality and magnitude of floods in Switzerland 
under future climate change. Hydrol Processes 2013, 28:2567-2578. doi: 10.1002/hyp.9757.

9. Oki T, Agata Y, Kanae S, Saruhashi T, Musiake K. Global water resources assessment under climatic change in 2050 using TRIP. In: Franks S, Blöschl G, Kumagai M, Musiake K, Rosbjerg D, eds. Water Resources Systems - Water Availability and Global Change. Wallingford: IAHS Press; 2003, 124-133.

10. Milano M, Ruelland D, Fernandez S, Dezetter A, Fabre J. Facing climatic and anthropogenic changes in the Mediterranean basin: what will be the medium-term impact on water stress? C R Geoscience 2012, 344:432-440.

11. Gobiet A, Kotlarski S, Beniston M, Heinrich G, Rajczak J, Stoffel M. 21st century climate change in the European Alps-a review. Sci Total Environ 2013. doi: 10.1016/j.scitotenv.2013.07.050.

12. Rahman K, Maringanti C, Beniston M, Widmer F, Abbaspour K, Lehmann A. Streamflow modeling in a highly managed mountainous glacier watershed using SWAT: the Upper Rhone River watershed case in Switzerland. Water Resour Manage 2013, 27:323-339. doi: 10.1007/s11269-012-0188-9.

13. Stahl K, Hisdal H, Hannaford J, Tallaksen LM, van Lanen HAJ, Sauquet E, Demuth S, Fendekova M, Jodar J. Streamflow trends in Europe: evidence from a dataset of near-natural catchments. Hydrol Earth Syst Sci 2010, 14:2367-2382.

14. Vanham D, Fleischhacker E, Rauch W. Impact of an extreme dry and hot summer on water supply security in an alpine region. Water Sci Technol 2009, 59:469-477.

15. Vanham D, Fleischhacker E, Rauch W. Impact of snowmaking on alpine water resources management under present and climate change conditions. Water Sci Technol 2009, 59:1793-1801.

16. Vanham D, Millinger S, Pliessnig H, Rauch W. Rasterised water demands: methodology for their assessment and possible applications. Water Resour Manage 2011, 25:3301-3320.

17. Hoekstra AY, Mekonnen MM, Chapagain AK, Mathews RE, Richter BD. Global monthly water scarcity: blue water footprints versus blue water availability. PLoS One 2012, 7:e32688. doi: 10.1371/journal.pone. 0032688.

18. Huss M, Voinesco A, Hoelzle M. Implications of climate change on Glacier de la Plaine Morte, Switzerland. Geogr Helv 2013, 68:227-237.

19. Finger D, Hugentobler A, Huss M, Voinesco A, Wernli H, Fischer D, Weber E, Jeannin PY, Kauzlaric M, Wirz A, et al. Identification of glacial meltwater runoff in a karstic environment and its implication for present and future water availability. Hydrol Earth Syst Sci 2013, 17:3261-3277. doi: 10.5194/hess-17-3261-201.

20. Reynard E, Bonriposi M. Water use management in dry mountains of Switzerland. The case of Crans-Montana-Sierre area. In: Neményi M, Balint
$\mathrm{H}$, eds. The Impact of Urbanisation, Industrial, Agricultural and Forest Technologies on the Natural Environment. Sopron: Nyugat-magyarorszagi Egyetem; 2012, 281-301.

21. Schneider F. Approaching water stress in the Alps: transdisciplinary co-production of systems, target and transformation knowledge. In: Borsdorf A, Stötter J, Veulliet E, eds. Managing Alpine Future II - Inspire and Drive Sustainable Mountain Regions. Proceedings of the Innsbruck Conference, November 21-23, 2011. Wien: Verlag der Österreichischen Akademie der Wissenschaften; 2011, 107-117.

22. Schneider F, Reynard E, Bonriposi M, Graefe M, Herweg K, Homewood C, Huss M, Kauzlaric M, Liniger H, Rey E, Rist S, Schädler B, Weingartner R. Assessing the sustainability of water governance systems: the sustainability wheel. J Environ Plann Manage. Submitted for publication.

23. Kumar M. Toward a hydrologic modelling system. $\mathrm{PhD}$ Thesis, Department of civil and Environmental engineering, Pennsylvania State University, University Park, PA, 2009, 274.

24. MeteoSwiss. Daily precipitation (final analysis): RhiresD. 2010. Available at: http://www.meteoschweiz. admin.ch/web/de/services/datenportal/gitterdaten/pre cip/rhiresd.html (accessed 31 May 2014).

25. Bonriposi M. Analyse systémique et prospective des usages de l'eau dans la région de Crans-Montana-Sierre (Suisse). PhD Thesis, Faculty of Geosciences and Environment, University of Lausanne, 2013, 300. Available at: http://www.unil.ch/igul/page83721.html (accessed 31 May 2014).

26. Schneider F, Homewood C. Exploring water governance arrangements in the Swiss Alps from the perspective of adaptive capacity. Mt Res Dev 2013, 33:225-233. doi: 10.1659/MRD-JOURNAL-D-1300004.1.

27. Bosshard T, Kotlarski S, Ewen T, Schär C. Spectral representation of the annual cycle in the climate change signal. Hydrol Earth Syst Sci 2011, 15:2777-2788. doi: 10.5194/hess-15-2777-2011.

28. CH2011. Swiss Climate Change Scenarios CH2011. Zurich: C2SM, MeteoSwiss, ETH, NCCR Climate, OcCC; 2011, 88.

29. Huss M, Farinotti D, Bauder A, Funk M. Modelling runoff from highly glacierized alpine drainage basins in a changing climate. Hydrol Processes 2008, 22:3888-3902.

30. Berkhout F, Hertin J. Foresight futures scenarios. Developing and applying a participative strategic planning tool. Greener Manage Int 2002, 37:37-52.

31. Shackley S, Deanwood R. Constructing social futures for climate-change impacts and response studies: building qualitative and quantitative scenarios with the participation of stakeholders. Clim Res 2003, 24:71-90. 
32. Holman IP, Rounsevell MDA, Shackley S, Harrison PA, Nicholls RJ, Berry PM, Audsley E. A regional, multi-sectoral and integrated assessment of the impacts of climate and socio-economic change in the UK: Part I. Methodology. Clim Change 2005, 71:9-41.

33. Holman IP, Nicholls RJ, Berry PM, Harrison PA, Audsley E, Shackley S, Rounsevell MDA. A regional, multi-sectoral and integrated assessment of the impacts of climate and socio-economic change in the UK: Part II. Results. Clim Change 2005, 71:43-73.

34. Schneider F, Rist S. Envisioning sustainable water futures in a transdisciplinary learning process: combining normative, explorative, and participatory scenario approaches. Sustainability Sci 2013:1-19. doi: 10.1007/s11625-013-0232-6.

35. Schär C, Vidale PL, Lüthi D, Frei C, Häberli C, Liniger MA, Appenzeller C. The role of increasing temperature variability in European summer heatwaves. Nature 2004, 427:332-336. doi: 10.1038/nature02300.

36. Reynard E. Aménagement du territoire et gestion de l'eau dans les stations touristiques alpines. Le cas de Crans-Montana-Aminona (Valais, Suisse. Revue de Géographie Alpine 2001, 89:7-19.
37. Bréthaut C. Le fonctionnement du réseau d'eau d'une station touristique : spécificités et réinterprétation locale des règles. Flux 2013, 92:36-46.

38. Reynard E. Cadre institutionnel et gestion des ressources en eau dans les Alpes: deux études de cas dans des stations touristiques valaisannes. Swiss Pol Sci Rev 2000, 6:53-85.

39. Reynard E, Bonriposi M, Graefe O, Herweg K, Homewood C, Huss M, Kauzlaric M, Liniger H, Rey E, Rist S, et al. MontanAqua. Anticiper le Stress Hydrique Dans les Alpes? Scénarios de Gestion de l'eau Dans la Région de Crans-Montana-Sierre (Valais). Résultats Finaux et Recommandations. Lausanne et Fribourg: Universités de Berne; 2013, 10.

40. Loucks DP, Gladwell JS. Sustainability Criteria for Water Resource Systems. Cambridge: Cambridge University Press; 1999, 139.

41. Schneider F, Buser T, Graefe O. Scales of justice in water governance: hydropower controversies in Switzerland. Special issue of Water policy: Why Justice Matters in Water Governance. Submitted for publication. 